\title{
Synthesis of Coral-Like, Straw-Tied-Like, and Flower-Like Antimony Sulfides by a Facile Wet-Chemical Method
}

\author{
Jutarat Kavinchan, ${ }^{1}$ Titipun Thongtem, ${ }^{2}$ Somchai Thongtem, ${ }^{3,4}$ and Eksuree Saksornchai ${ }^{1}$ \\ ${ }^{1}$ Division of Chemistry, School of Science, University of Phayao, Phayao 56000, Thailand \\ ${ }^{2}$ Department of Chemistry, Faculty of Science, Chiang Mai University, Chiang Mai 50200, Thailand \\ ${ }^{3}$ Department of Physics and Materials Science, Faculty of Science, Chiang Mai University, Chiang Mai 50200, Thailand \\ ${ }^{4}$ Materials Science Research Center, Faculty of Science, Chiang Mai University, Chiang Mai 50200, Thailand
}

Correspondence should be addressed to Titipun Thongtem; ttpthongtem@yahoo.com

and Somchai Thongtem; schthongtem@yahoo.com

Received 30 May 2013; Revised 26 June 2013; Accepted 27 June 2013

Academic Editor: Jiamin Wu

Copyright ( 2013 Jutarat Kavinchan et al. This is an open access article distributed under the Creative Commons Attribution License, which permits unrestricted use, distribution, and reproduction in any medium, provided the original work is properly cited.

Antimony sulfide $\left(\mathrm{Sb}_{2} \mathrm{~S}_{3}\right)$ was successfully synthesized from antimony chloride $\left(\mathrm{SbCl}_{3}\right)$ and sodium thiosulfate pentahydrate $\left(\mathrm{Na}_{2} \mathrm{~S}_{2} \mathrm{O}_{3} \cdot 5 \mathrm{H}_{2} \mathrm{O}\right)$ in ethylene glycol (EG) without using any template by a facile wet-chemical method. X-ray diffraction (XRD), scanning electron microscopy (SEM), and transmission electron microscopy (TEM) show that the products were orthorhombic $\mathrm{Sb}_{2} \mathrm{~S}_{3}$ nanorods forming the coral-like, straw-tied-like, and flower-like architectures with the nanorods growing along the [001] direction. The energy gap $\left(\mathrm{E}_{\mathrm{g}}\right)$ was determined by UV-visible absorption to be $1.52 \mathrm{eV}$.

\section{Introduction}

$\mathrm{Sb}_{2} \mathrm{~S}_{3}$ is an orthorhombic V-VI semiconductor with 1.78 $2.50 \mathrm{eV}$ direct band gap, covering the visible and near IR range of solar spectrum [1]. It has a potential application for solar cells and thermoelectric and optoelectronic devices $[1,2]$. A number of processes were used to synthesize antimony sulfide with different morphologies: single-crystal $\mathrm{Sb}_{2} \mathrm{~S}_{3}$ nanotubes via EDTA-assisted hydrothermal route [1], nanocrystalline $\mathrm{Sb}_{2} \mathrm{~S}_{3}$ by microwave-assisted synthesis [2], $\mathrm{Sb}_{2} \mathrm{~S}_{3}$ peanutshaped superstructures [3], rod-like $\mathrm{Sb}_{2} \mathrm{~S}_{3}$ dendrites [4] and $\mathrm{Sb}_{2} \mathrm{~S}_{3}$ nanorods [5] by hydrothermal reaction, double sheaflike $\mathrm{Sb}_{2} \mathrm{~S}_{3}$ by copolymer-assisted hydrothermal synthesis [6], $\mathrm{Sb}_{2} \mathrm{~S}_{3}$ nanowires [7] and $\mathrm{Sb}_{2} \mathrm{~S}_{3}$ nanoribbons [8] by solvothermal route, $\mathrm{Sb}_{2} \mathrm{~S}_{3}$ nanowires by PEG-assisted solvothermal process [9], and orthorhombic $\mathrm{Sb}_{2} \mathrm{~S}_{3}$ twin flowers in the solutions containing CTAB by a cyclic microwave radiation [10]. Crystal structures, crystalline degree, different phases, purities, defects, and others can play a role in the properties of materials, such as strength and corrosion resistance, including electrical and thermal conductivities. Previously, $\mathrm{Sb}_{2} \mathrm{~S}_{3}$ with different morphologies was successfully synthesized by different methods: straw-tied-like architectures by a one-pot hydrothermal method both with and without CTAB as an additive [11], hydrothermal synthesis [12], a novel precursorsolvothermal-pyrolysis route [13], and a refluxing polyol process of the solution containing PVP as a surfactant [14], including flower-like $\mathrm{Sb}_{2} \mathrm{~S}_{3}$ by a refluxing polyol process of the solution containing PVP as a surfactant [14] and a refluxing method of the solution containing PEG400 as a surfactant [15]. The above methods require high temperature and pressure, different additives, and complicated equipment. Thus, the purpose of the present research is to synthesize $\mathrm{Sb}_{2} \mathrm{~S}_{3}$ with different morphologies by a facile wet-chemical method without using a template. This method is novel, very simple, and inexpensive. The influences of the experimental parameters on the structures and morphologies were also investigated.

\section{Experiment}

A wet-chemical route was used in this research of which $0.002 \mathrm{~mol} \mathrm{SbCl}_{3}$ (assay: 99\%, Sigma-Aldrich) and $0.003 \mathrm{~mol}$ 


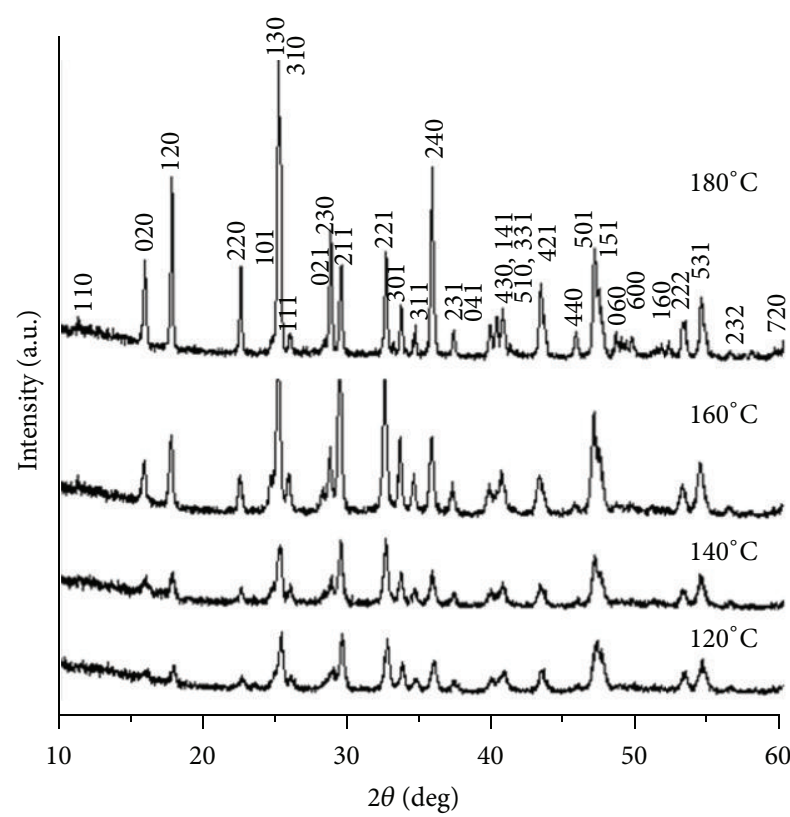

(a)

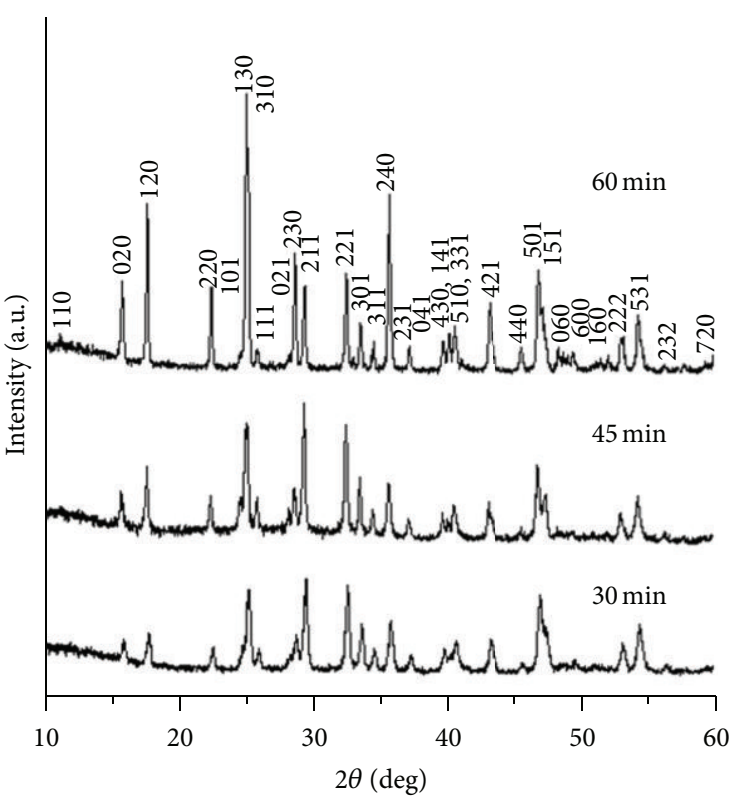

(b)

FIgURE 1: XRD spectra of the products synthesized at (a) $120,140,160$, and $180^{\circ} \mathrm{C}$ for $60 \mathrm{~min}$ and (b) $180^{\circ} \mathrm{C}$ for 30 , 45 , and $60 \mathrm{~min}$ in $\mathrm{EG}$.

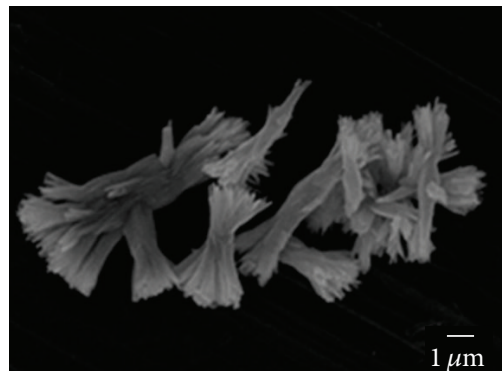

(a)

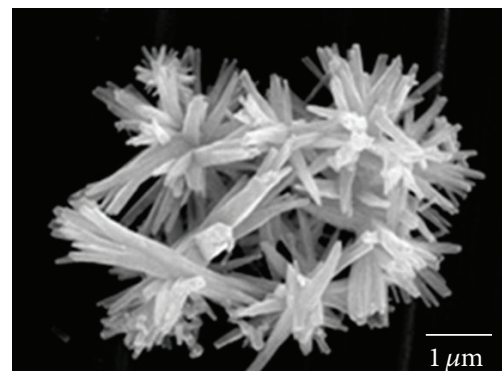

(b)

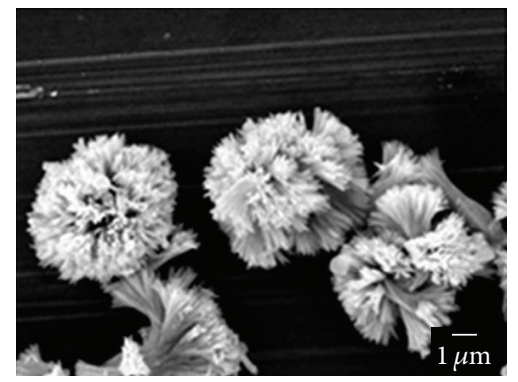

(c)

Figure 2: SEM images of $\mathrm{Sb}_{2} \mathrm{~S}_{3}$ synthesized in EG at (a)-(c) $120^{\circ} \mathrm{C}, 140^{\circ} \mathrm{C}$, and $160^{\circ} \mathrm{C}$ for 60 min, respectively.

$\mathrm{Na}_{2} \mathrm{~S}_{2} \mathrm{O}_{3} \cdot 5 \mathrm{H}_{2} \mathrm{O}$ (assay: $\geq 99.5 \%$, Sigma-Aldrich) were dissolved in $30 \mathrm{~mL}$ ethylene glycol (EG, assay: 99.5\%, QReC) and mixed homogeneously by $15 \mathrm{~min}$ stirring in a beaker at room temperature. Subsequently, orange colloidal complexes immediately formed. To synthesize $\mathrm{Sb}_{2} \mathrm{~S}_{3}$ with different morphologies, each of the solutions was directly heated in an electric oven at different constant temperatures of 180 , 160,140 , and $120^{\circ} \mathrm{C}$ for $60 \mathrm{~min}$, including at a constant temperature of $180^{\circ} \mathrm{C}$ for 30 and $45 \mathrm{~min}$. Finally, black precipitates were synthesized, separated by filtration, washed with absolute ethanol, and dried at $70^{\circ} \mathrm{C}$ for $24 \mathrm{~h}$.

The products were characterized by an X-ray diffractometer (XRD, SIEMENS D500) operating at $20 \mathrm{kV}, 15 \mathrm{~mA}$, and using $\mathrm{Cu}-\mathrm{K}_{\alpha}$ line from a copper target; a scanning electron microscope (SEM, JEOL JSM-6335F) equipped with an energy dispersive X-ray (EDX) analyzer operating at $15 \mathrm{kV}$; a transmission electron microscope (TEM, JEOL JEM-2010) as well as a high-resolution transmission electron microscope
(HRTEM) and selected area electron diffractometer (SAED) operating at $200 \mathrm{kV}$; and a UV-visible spectrometer (Lambda 25 PerkinElmer) using a UV lamp with the resolution of $1 \mathrm{~nm}$.

\section{Results and Discussion}

Figure 1 shows XRD spectra of the products synthesized under different temperatures and lengths of time. At different temperatures of $180,160,140$, and $120^{\circ} \mathrm{C}$ for $60 \mathrm{~min}$, the products were specified as orthorhombic $\mathrm{Sb}_{2} \mathrm{~S}_{3}$ (JCPDS number 06-0474) [16] with pure crystal. To save energy consumption, the temperature was reduced in series of steps from 180 to $120^{\circ} \mathrm{C}$. The results show that the intensity of XRD spectra became lowered and the crystalline degree was lessened. At $180^{\circ} \mathrm{C}$ for different lengths of time in EG, XRD spectra became sharper and narrower by increasing the lengths of time from 30 to $60 \mathrm{~min}$, and the crystalline degree was improved in sequence. 


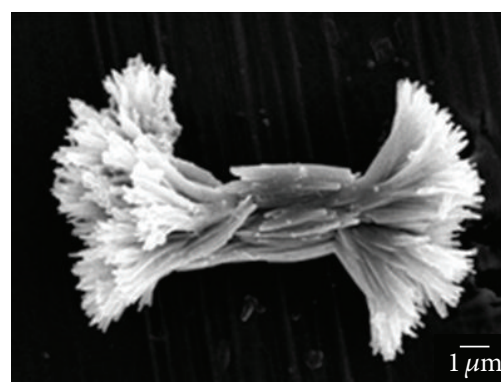

(a)

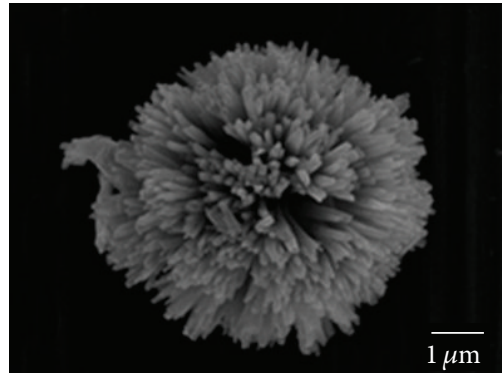

(c)

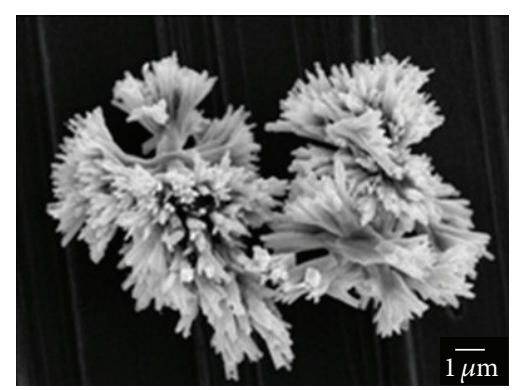

(b)

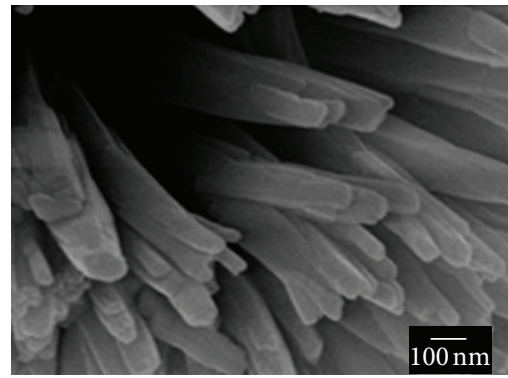

(d)

FIgURE 3: SEM images of $\mathrm{Sb}_{2} \mathrm{~S}_{3}$ synthesized in EG at $180^{\circ} \mathrm{C}$ for (a) $30 \mathrm{~min}$, (b) $45 \mathrm{~min}$, and (c, d) $60 \mathrm{~min}$.

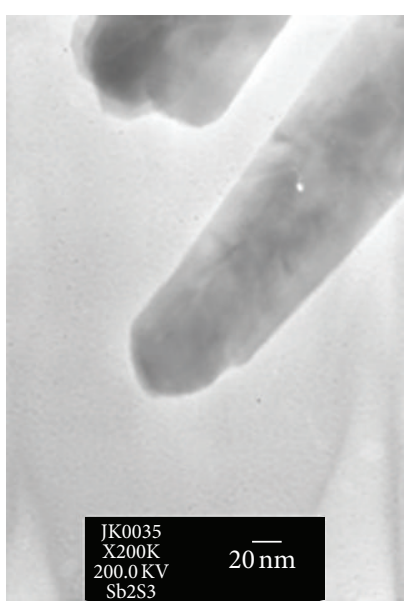

(a)

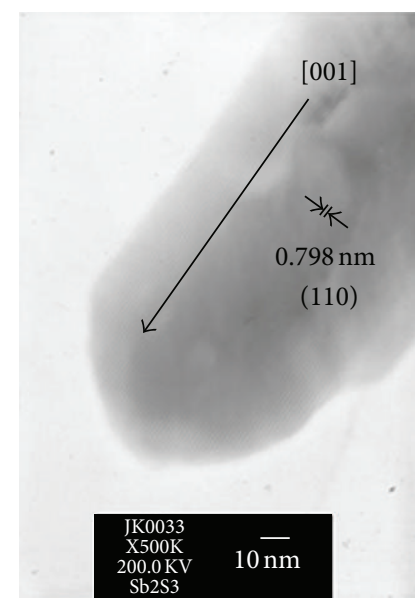

(b)

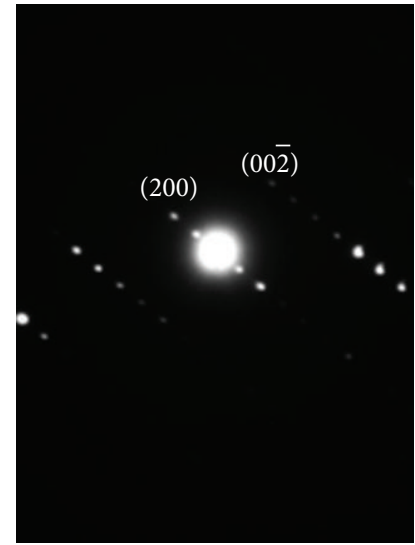

(c)

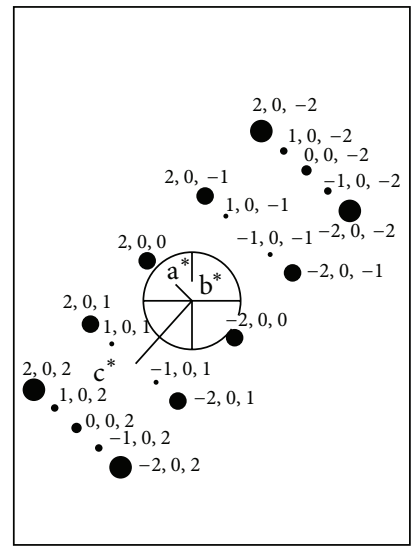

(d)

FIgURE 4: (a), (b) TEM and HRTEM images, (c) SAED, and (d) simulated patterns of $\mathrm{Sb}_{2} \mathrm{~S}_{3}$ synthesized by wet-chemical method at $180^{\circ} \mathrm{C}$ for $60 \mathrm{~min}$.

In the present research, $\mathrm{SbCl}_{3}$ and $\mathrm{Na}_{2} \mathrm{~S}_{2} \mathrm{O}_{3}$ were mixed in EG by 15 min stirring, and orange colloidal complexes formed:

$$
\mathrm{SbCl}_{3}+\mathrm{Na}_{2} \mathrm{~S}_{2} \mathrm{O}_{3} \stackrel{15 \text { min stirring }}{\longrightarrow} \text { Orange colloidal complexes }
$$

The orange colloidal complexes were the intermediate products, which were subsequently transformed into $\mathrm{Sb}_{2} \mathrm{~S}_{3}$ black precipitates by heating at high temperatures:

$$
\text { Orange colloidal complexes } \stackrel{\text { high temperature heating in oven }}{\longrightarrow} \mathrm{Sb}_{2} \mathrm{~S}_{3} \text { (black) }
$$

SEM images (Figures 2 and 3) show $\mathrm{Sb}_{2} \mathrm{~S}_{3}$ products synthesized at different temperatures and lengths of time. Their surfaces were smooth and clean. Increasing in the temperatures and lengths of time has the influence on the change in morphology of the products. For those synthesized at different temperatures, the as-produced $\mathrm{Sb}_{2} \mathrm{~S}_{3}$ was straw-tied-like architecture at $120^{\circ} \mathrm{C}$ for $60 \mathrm{~min}$. Then, the temperature was increased to $140^{\circ} \mathrm{C}$ with the length of time kept constant for $60 \mathrm{~min}$; the product transformed into corallike architecture. Finally, the products gradually transformed into nanostructured flowers at 160 and $180^{\circ} \mathrm{C}$ within $60 \mathrm{~min}$. Moreover, the length of time also has the influence on 


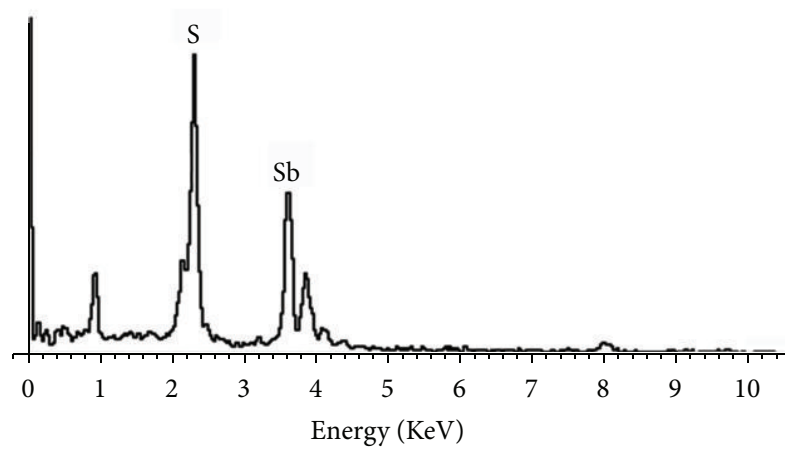

FIGURE 5: EDX spectrum of $\mathrm{Sb}_{2} \mathrm{~S}_{3}$ synthesized by wet-chemical method at $180^{\circ} \mathrm{C}$ for $60 \mathrm{~min}$.

the morphology formation of $\mathrm{Sb}_{2} \mathrm{~S}_{3}$. SEM images of the products at $180^{\circ} \mathrm{C}$ for different lengths of time were compared. The $\mathrm{Sb}_{2} \mathrm{~S}_{3}$ product, synthesized at $180^{\circ} \mathrm{C}$ for $30 \mathrm{~min}$, was straw-tied-like architecture with a number of rods split at their ends. The extent of opening or splitting was influenced by the temperatures and lengths of time. As time passed, nanorods formed, grew, and split at their ends $[17,18]$. Hence, the flower-like architecture began to form at $180^{\circ} \mathrm{C}$ for $45 \mathrm{~min}$ and constantly formed at $180^{\circ} \mathrm{C}$ for $60 \mathrm{~min}$. At this stage, the as-synthesized product became complete flowers. The present phenomenon is similar to the report of Zhu et al. [15] who stated that flower-like structured $\mathrm{Sb}_{2} \mathrm{~S}_{3}$ could be transformed into nanorods by increasing in the length of time from 1 to $2 \mathrm{~h}$ during $85^{\circ} \mathrm{C}$ refluxing of the solutions containing PEG400. Previously, orthorhombic $\mathrm{Sb}_{2} \mathrm{~S}_{3}$ twin flowers, composed of single crystalline square nanorod petals, were successfully synthesized in the solutions containing CTAB as a template and splitting agent by a cyclic microwave radiation [10], including the flower-like $\mathrm{Sb}_{2} \mathrm{~S}_{3}$ by refluxing polyol process of the solution containing PVP as a surfactant [14] and by refluxing method of the solution containing PEG400 as a surfactant [15]. But for the present research, $\mathrm{Sb}_{2} \mathrm{~S}_{3}$ coral-like and flower-like architectures were successfully synthesized by a facile wet-chemical method without the use of any template and splitting agent.

TEM and HRTEM images, SAED, and simulated patterns [19] of $\mathrm{Sb}_{2} \mathrm{~S}_{3}$ synthesized in $\mathrm{EG}$ at $180^{\circ} \mathrm{C}$ for $60 \mathrm{~min}$ are shown in Figure 4. TEM and HRTEM images show the flowerlike architecture which consisted of nanorods. SAED and simulated patterns of the synthesized $\mathrm{Sb}_{2} \mathrm{~S}_{3}$ also show that each flower was composed of $\mathrm{Sb}_{2} \mathrm{~S}_{3}$ nanorods, growing along the [001] direction (along the $c$-axis) - in accordance with the growth direction characterized by Yang et al. [2], Wang et al. [11], Ota et al. [17], and Hu et al. [20]. The (110) planes along the growth direction were also detected, showing that the nanorod was single crystal. In addition, the interpreted SAED pattern, composed of bright spots in lattice array, was specified that each nanorod was single crystal, corresponding to orthorhombic $\mathrm{Sb}_{2} \mathrm{~S}_{3}$ [16]. To justify the presence of $\mathrm{Sb}_{2} \mathrm{~S}_{3}$ single crystal, its pattern was simulated [19] and appears as systematic spots-in good accordance with the above interpretation.

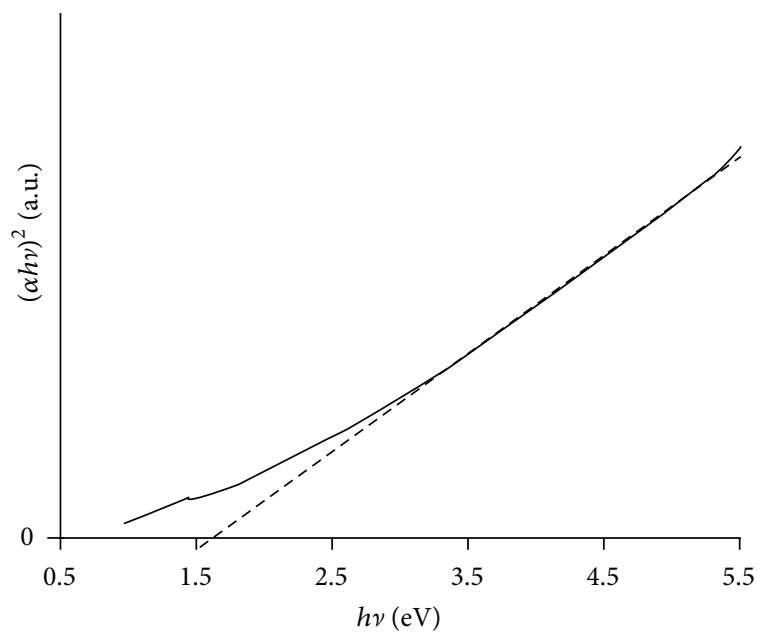

FIgure 6: The $(\alpha h \nu)^{2}$ and $h \nu$ plot of $\mathrm{Sb}_{2} \mathrm{~S}_{3}$ synthesized by wetchemical method at $180^{\circ} \mathrm{C}$ for $60 \mathrm{~min}$.

Figure 5 shows the EDX spectroscopy measurement of $\mathrm{Sb}_{2} \mathrm{~S}_{3}$ synthesized at $180^{\circ} \mathrm{C}$ for $60 \mathrm{~min}$. It shows the characteristic peaks of only $\mathrm{S}\left(\mathrm{K}_{\alpha 1,2}\right.$ at $\left.2.31 \mathrm{keV}\right)$ and $\mathrm{Sb}\left(\mathrm{L}_{\alpha}\right.$ at $3.61 \mathrm{keV}$ and $\mathrm{L}_{\beta 1}$ at $3.84 \mathrm{keV}$ ), suggesting that the product contains only antimony and sulfur elements. Quantitative EDX analysis shows that the atomic ratio of $\mathrm{Sb}: \mathrm{S}$ was $40.85: 59.15$, close to $2: 3$, confirming that the product was really crystalline $\mathrm{Sb}_{2} \mathrm{~S}_{3}$. It should be noted that $\mathrm{Cu}$ of the stub was also detected at $0.93 \mathrm{keV}\left(\mathrm{L}_{\alpha}\right)$ and $8.04 \mathrm{keV}\left(\mathrm{K}_{\alpha 1,2}\right)$.

An optical absorption experiment has been carried out using a UV-vis absorption spectrometer, which provides an effective method for explaining some features concerning the band structure of $\mathrm{Sb}_{2} \mathrm{~S}_{3}$ nanorods. Figure 6 shows the $(\alpha h v)^{2}$ and $(h \nu)$ plot for the direct allowed transition, where $\alpha, h$, and $v$ are the total absorption coefficient, Planck constant, and photonic frequency, respectively $[1,15]$. In this research, the photonic wave attenuated through the solid. The change of photonic absorption was controlled by two photonic energy ranges. When the photonic energy is higher than the energy gap, absorption was linearly increased with the increasing of photonic energy. But for the photonic energy with less than the energy gap, the absorption became different from linearity which was influenced by the absorption relating to defect levels between the valence and conduction bands of the product. Its band gap, determined by extrapolation of the linear curve to zero absorbance, corresponds to $1.52 \mathrm{eV}-$ in accordance with $1.52 \mathrm{eV}$ band gap of $\mathrm{Sb}_{2} \mathrm{~S}_{3}$ nanorods determined by Zhu et al. [15]. It should be noted that this value is less than the $2.43 \mathrm{eV}$ of the as-deposited thin film [21] and $1.95 \mathrm{eV}$ thin film deposited on the $300 \mathrm{~K}$ substrate [22], which were lessened by high-temperature annealing $[21,22]$. This value is blue shift relative to $1.28 \mathrm{eV}$ energy gap of $\mathrm{Bi}_{2} \mathrm{~S}_{3}$ [23]. Generally, different morphologies and crystalline degrees can play a role in the properties of products, such as energy gap and photoluminescence (PL) [6,24-28]. The value of the band-gap energy for $\mathrm{Sb}_{2} \mathrm{~S}_{3}$ nanorods is close to the optimum value for the photovoltaic conversion, solar energy converters, and optical nanodevices [15]. 


\section{Conclusions}

The coral-like, straw-tied-like, and flower-like $\mathrm{Sb}_{2} \mathrm{~S}_{3}$ products were successfully synthesized by a facile wet-chemical method in EG. The phase was detected by XRD and SAED. SEM and TEM revealed the transformation of the assynthesized straw-tied-like at $120^{\circ} \mathrm{C}$ into flower-like at $180^{\circ} \mathrm{C}$. The flowers were good crystalline nanorods with $1.52 \mathrm{eV}$ direct band gap.

\section{Acknowledgments}

The authors wish to thank the Thailand's Office of the Higher Education Commission for providing financial support through the National Research University (NRU) project for Chiang Mai University and the National Nanotechnology Center (NANOTEC), National Science and Technology Development Agency, for providing financial support through the Project P-10-11345.

\section{References}

[1] G. Y. Chen, W. X. Zhang, and A. W. Xu, "Synthesis and characterization of single-crystal $\mathrm{Sb}_{2} \mathrm{~S}_{3}$ nanotubes via an EDTAassisted hydrothermal route," Materials Chemistry and Physics, vol. 123, no. 1, pp. 236-240, 2010.

[2] H. Yang, X. Su, and A. Tang, "Microwave synthesis of nanocrystalline $\mathrm{Sb}_{2} \mathrm{~S}_{3}$ and its electrochemical properties," Materials Research Bulletin, vol. 42, no. 7, pp. 1357-1363, 2007.

[3] Q. Han, L. Chen, W. Zhu et al., "Synthesis of $\mathrm{Sb}_{2} \mathrm{~S}_{3}$ peanutshaped superstructures," Materials Letters, vol. 63, no. 12, pp. 1030-1032, 2009.

[4] L. Chen, W. Zhu, Q. Han, X. Yang, L. Lu, and X. Wang, "Preparation of rod-like $\mathrm{Sb}_{2} \mathrm{~S}_{3}$ dendrites processed in conventional hydrothermal," Materials Letters, vol. 63, no. 15, pp. 1258-1261, 2009.

[5] C. Li, X. Yang, Y. Liu, Z. Zhao, and Y. Qian, "Growth of crystalline $\mathrm{Sb}_{2} \mathrm{~S}_{3}$ nanorods by hydrothermal method," Journal of Crystal Growth, vol. 255, no. 3-4, pp. 342-347, 2003.

[6] C. Pilapong, T. Thongtem, and S. Thongtem, "Hydrothermal synthesis of double sheaf-like $\mathrm{Sb}_{2} \mathrm{~S}_{3}$ using copolymer as a crystal splitting agent," Journal of Alloys and Compounds, vol. 507, no. 2, pp. L38-L42, 2010.

[7] Z. R. Geng, M. X. Wang, G. H. Yue, and P. X. Yan, "Growth of single-crystal $\mathrm{Sb}_{2} \mathrm{~S}_{3}$ nanowires via solvothermal route," Journal of Crystal Growth, vol. 310, no. 2, pp. 341-344, 2008.

[8] Y. Xinyu, Z. Jiasong, L. Lijun, L. Xiaojuan, L. Haitao, and X. Weidong, "L-cystine-assisted growth of $\mathrm{Sb}_{2} \mathrm{~S}_{3}$ nanoribbons via solvothermal route," Materials Chemistry and Physics, vol. 118, no. 2-3, pp. 432-437, 2009.

[9] G. Wang and C. L. Cheung, "Building crystalline $\mathrm{Sb}_{2} \mathrm{~S}_{3}$ nanowire dandelions with multiple crystal splitting motif," Materials Letters, vol. 67, no. 1, pp. 222-225, 2012.

[10] J. Kavinchan, T. Thongtem, and S. Thongtem, "Cyclic microwave assisted synthesis of $\mathrm{Sb}_{2} \mathrm{~S}_{3}$ twin flowers in solutions containing a template and splitting agent," Chalcogenide Letters, vol. 9, no. 9, pp. 365-370, 2012.

[11] D. Wang, C. Song, X. Fu, and X. Li, "Growth of one-dimensional $\mathrm{Sb}_{2} \mathrm{~S}_{3}$ and $\mathrm{Sb}_{2} \mathrm{Se}_{3}$ crystals with straw-tied-like architectures," Journal of Crystal Growth, vol. 281, no. 2-4, pp. 611-615, 2005.
[12] P. G. Sheikhiabadi, M. Salavati-Niasari, and F. Davar, "Hydrothermal synthesis and optical properties of antimony sulfide micro and nano-size with different morphologies," Materials Letters, vol. 71, pp. 168-171, 2012.

[13] M. Mo, Z. Zhu, X. Yang et al., "Growth of single-crystal $\mathrm{Sb}_{2} \mathrm{~S}_{3}$ nanorods, dendrites and straw-tied-like architectures via a precursor-solvothermal-pyrolysis route," Journal of Crystal Growth, vol. 256, no. 3-4, pp. 377-382, 2003.

[14] R. Zhang, X. Chen, M. Mo et al., "Morphology-controlled growth of crystalline antimony sulfide via a refluxing polyol process," Journal of Crystal Growth, vol. 262, no. 1-4, pp. 449455, 2004.

[15] Q. Zhu, M. Gong, C. Zhang, G. Yong, and S. Xiang, "Preparation of $\mathrm{Sb}_{2} \mathrm{~S}_{3}$ nanomaterials with different morphologies via a refluxing approach," Journal of Crystal Growth, vol. 311, no. 14, pp. 3651-3655, 2009.

[16] Powder Diffraction File, JCPDS-ICDD, 12 Campus Boulevard, Newtown Square, PA 19073-3273, USA, 2001.

[17] J. Ota, P. Roy, S. K. Srivastava, B. B. Nayak, and A. K. Saxena, "Morphology evolution of $\mathrm{Sb}_{2} \mathrm{~S}_{3}$ under hydrothermal conditions: flowerlike structure to nanorods," Crystal Growth and Design, vol. 8, no. 6, pp. 2019-2023, 2008.

[18] J. Tang and A. P. Alivisatos, "Crystal splitting in the growth of $\mathrm{Bi}_{2} \mathrm{~S}_{3}$," Nano Letters, vol. 6, no. 12, pp. 2701-2706, 2006.

[19] C. Boudias and D. Monceau, CaRIne Crystallography 3.1, DIVERGENT S.A., Compiègne, France, 1989-1998.

[20] H. Hu, M. Mo, B. Yang et al., "Solvothermal synthesis of $\mathrm{Sb}_{2} \mathrm{~S}_{3}$ nanowires on a large scale," Journal of Crystal Growth, vol. 258, pp. 106-112, 2003.

[21] N. J. Mathew, R. Oommen, and U. P. Rajalakshmi, "Optical and electrical studies on thermally evaporated $\mathrm{Sb}_{2} \mathrm{~S}_{3}$ thin films," Chalcogenide Letters, vol. 7, pp. 701-706, 2010.

[22] N. Tigau, V. Ciupina, G. I. Rusu, G. Prodan, and E. Vasile, "Influence of substrate temperature on the structural and optical properties of $\mathrm{Sb}_{2} \mathrm{~S}_{3}$ thin films," Romanian Journal of Physics, vol. 50, pp. 859-868, 2005.

[23] J. Lu, Z. Wang, Y. Zhang, and X. Zhou, "Hydrothermal synthesis of $\mathrm{Bi}_{2} \mathrm{~S}_{3}$ nanorods from a single-source precursor and their promotional effect on the photocatalysis of $\mathrm{TiO}_{2}$," Journal of Nanomaterials, vol. 2013, Article ID 125409, 6 pages, 2013.

[24] T. Thongtem, S. Jattukul, C. Pilapong, and S. Thongtem, "Hydroxyethyl cellulose-assisted hydrothermal synthesis of $\mathrm{Bi}_{2} \mathrm{~S}_{3}$ urchin-like colonies," Current Applied Physics, vol. 12, no. 1, pp. 23-30, 2012.

[25] S. Thongtem, C. Wichasilp, and T. Thongtem, "Transient solidstate production of nanostructured CuS flowers," Materials Letters, vol. 63, no. 28, pp. 2409-2412, 2009.

[26] S. Kaowphong, T. Thongtem, O. Yayapao, and S. Thongtem, "The effect of solvents on $\mathrm{ZnS}$ nanostructures synthesized by biomolecule-assisted solvothermal method," Materials Letters, vol. 65, no. 23-24, pp. 3405-3407, 2011.

[27] T. Thongtem, A. Phuruangrat, and S. Thongtem, "Free surfactant synthesis of microcrystalline CdS by solvothermal reaction," Materials Letters, vol. 61, no. 14-15, pp. 3235-3238, 2007.

[28] T. Thongtem, C. Pilapong, and S. Thongtem, "Solvothermal synthesis of CdS nanorods using hydroxyethyl cellulose as a template," Current Applied Physics, vol. 9, no. 6, pp. 1272-1277, 2009. 

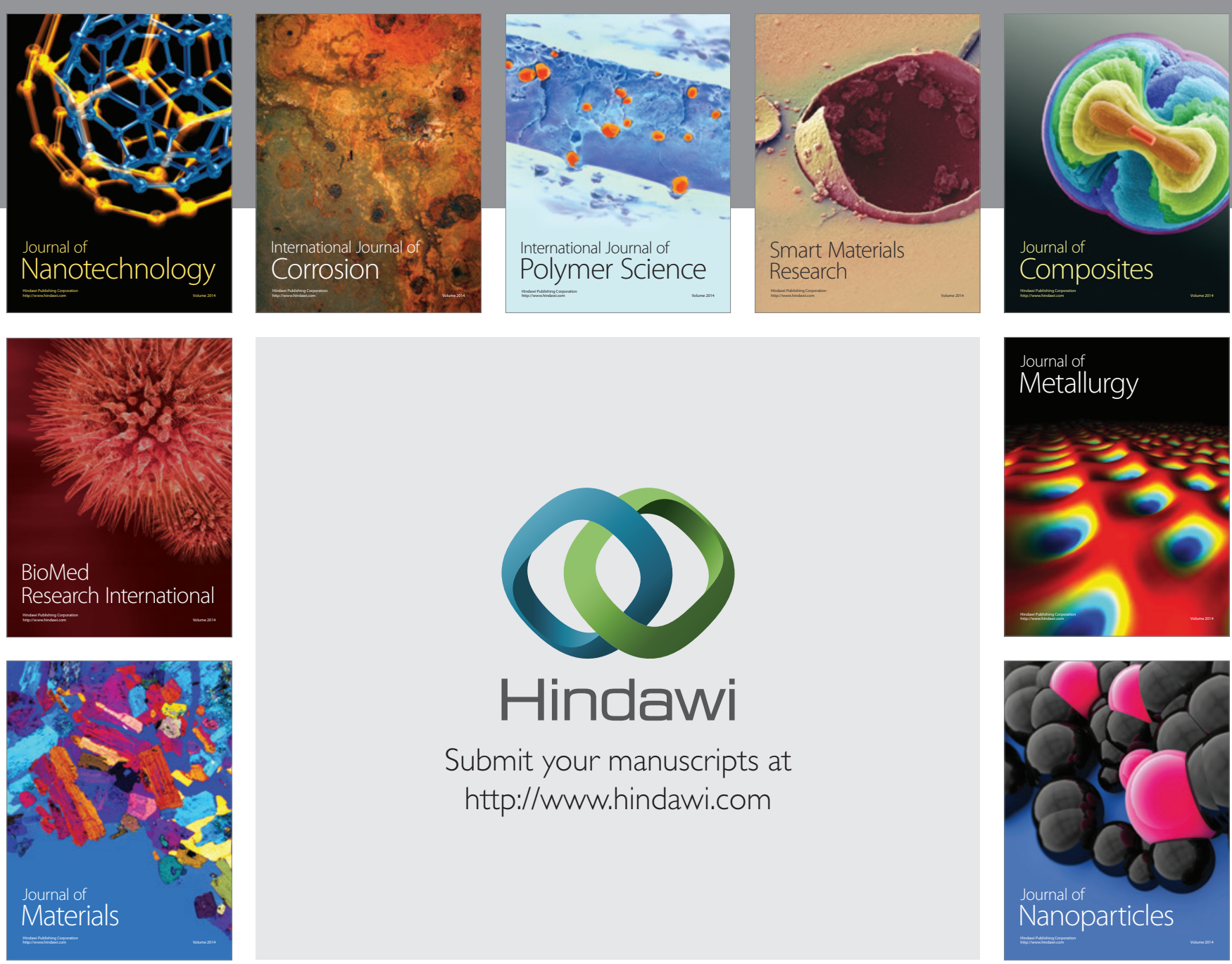

Submit your manuscripts at http://www.hindawi.com
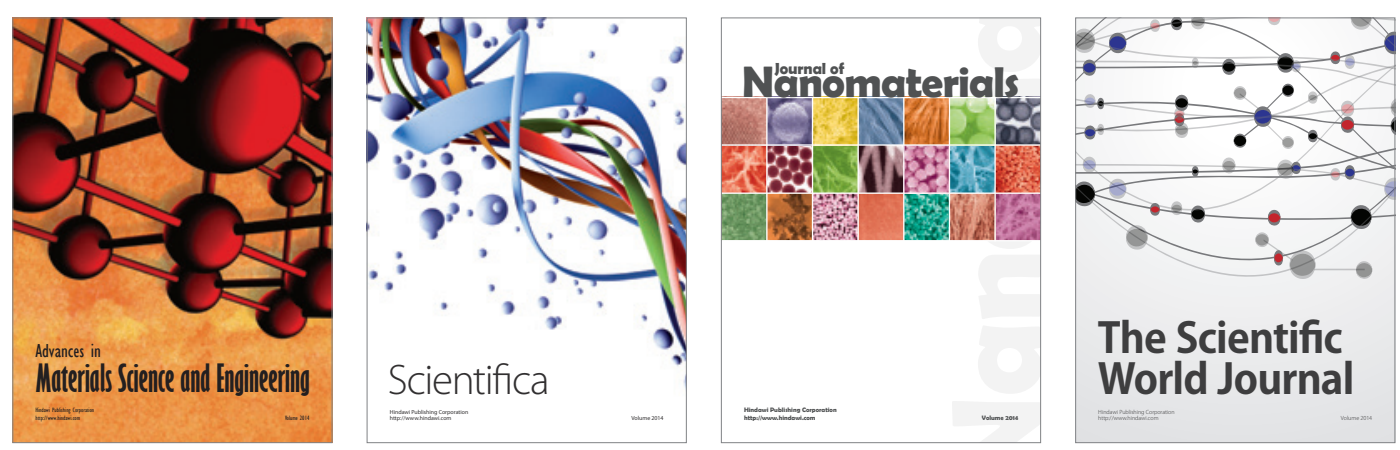

\section{The Scientific World Journal}
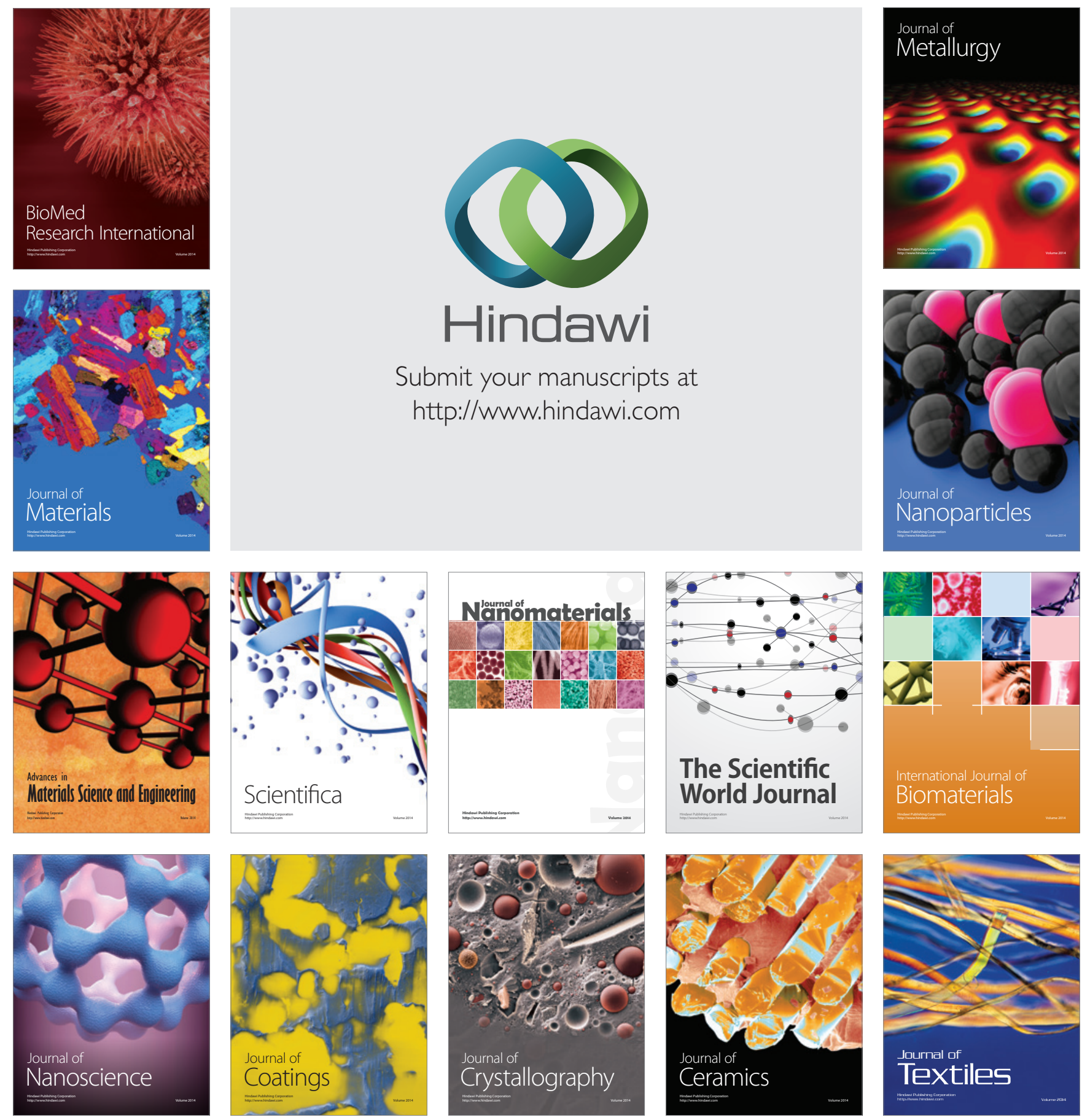